\title{
Serra and Sacred Song at the Founding of California's First Missions
}

\author{
Craig H. Russell
}

Music played a central role in the daily life of "modern" California, from its inception in 1769 and the founding of San Diego under the guidance of Junípero Serra, up through the secularization of the missions and beginning of the "American" period in the mid-nineteenth century. ${ }^{1}$ It permeated most sacred and social gatherings; the singing of mass and songs of praise was an obligatory part of quotidian life, and social functions revolved around festive music making. The guitar, for example, was as necessary at a picnic as was the food, and weddings or baptisms were marked by pageantry, processions, and dancing —all of which were accompanied by the dulcet sounds of musical accompaniment. ${ }^{2}$ Music was critically important, even in the earliest days of the mission period, yet relatively little has been written about its role during the founding days of these institutions. This article will examine music's role in the first two years of California's mission history (1769 and 1770), paying particular attention to Serra's inclusion of sacred music at the founding of the Carmel Mission during the feast of Pentecost in 1770.

As Father Serra progressed on his trek northward to Alta California, he wended his way through the various missions of Baja California. On 14 May 1769, he jotted down in his diary the events as they transpired at the founding of the San Fernando Mission near Vellicatá, Baja California, detailing the manner in which he celebrated the holy feast of Pentecost in this remote outpost. Perusing his account, one is struck by the martial pageantry of the service-gunfire was as memorable as the singing — and by Serra's makeshift improvisations in patching together the necessary elements for the celebration of mass from the ad hoc employment of available resources. He writes,

In order to give Holy Communion to the captain and the soldiers, [Father Fermín Francisco de Lasuén] had to come from Santa María to hear their confessions for them to make their Easter duty, and in preparation for the expedition. They say that this Mass was the very first, for 
although on his trip the Jesuit Father Link had been here, as referred to in his diary, the soldiers who escorted him declared he did not celebrate at this place. In this hut, then, was prepared an altar, the soldiers putting on their full accoutrement, leather jackets and shields, and with all the surroundings of holy poverty, I celebrated the Mass on that great day, consoled with the thought that it was the first of many to be continued permanently in this new Mission of San Fernando, thus founded that very day. While the celebration lasted, repeated discharges of firearms by the soldiers added to the solemnity: and for once the smoke of powder took the place of burning incense, which we could not use because we had none with us. And having no other candle than a stub I happened to have, and a small candle belonging to the Father, there was only one Mass, at which the Father assisted together with the soldier[s] in fulfillment of the obligation. After that we sang the Veni Creator [Spiritus in the eighth mode]. The congregation was made up of ourselves, the soldiers, and the Indian neophytes who came with us, while no gentile dared come near, frightened perhaps by so much shooting. ${ }^{3}$

Francisco Palóu, Serra's biographer, recounts the same event in language very similar to Serra's, but in passing he also alludes to the fact that they were lacking the organ and other instruments for accompaniment, clearly implying that the "expected" and most desirable performance would have been one in the canto de órgano or canto figurado traditions. His history informs us:

The following day, the 14th of May as has been established-and Whitsunday, the first day of Pentecost — the [mission] was inaugurated.... And having sung the first Mass, he delivered a fervent speech on the coming of the Holy Spirit and the establishment of the mission. Having finished the Holy Office that was celebrated without any more lights than those of a small taper and another small stub of a candle, and since the shipments in which the candle wax was coming had not arrived yet, he [Father Serra] sang the Veni Creator Spiritus, making up for the lack of an organ and the other musical instruments through the continual shots of the troops, who fired continuously during the function. And the smoke of the gunpowder took the place of the incense that they did not have. ${ }^{4}$

\section{Veni Creator Spiritus}

Veni Creator Spiritus, the selection mentioned by name in both Serra's and Palóu's recollections of the day's events, was a cornerstone in the mission repertoire, performed at the founding of missions and other important occasions. ${ }^{5}$ As will soon be seen, it was one of the pieces sung at the founding of the Carmel Mission in Monterey in 1770. 
In 1780, the mother institution of the Colegio Apostólico de San Fernando in Mexico City even codified this de facto tradition by requiring that the piece be sung the first evening at the founding of a new mission. With the friars singing its memorable strains, the men and women who assembled for the spectacle were to line up behind the Franciscans as they formed a procession. ${ }^{6}$ The fact that very few mission sources jot down the melody is not terribly surprising, for the tune was quite catchy, repetitive, and known by all who grew up in Mexican and Spanish culture. If everyone already knows a melody-like the tune to "Yankee Doodle" or "Happy Birthday" — why squander valuable paper with scribbling down the obvious? As with all hymns (and unlike the other genres of plainchant), Veni Creator Spiritus is strophic in form, that is, the melody is mapped out in the opening stanza and then comes back over and over again, with this recurring tune accommodating each subsequent stanza of text. Memorization, therefore, is not much of an issue, and the fact that it is exceedingly easy to learn makes it ideal as an opening salvo for the attempted conversion of new souls by the friars; after two or three times through the loop, almost anyone can catch on and jump into the thick of things.

Although Veni Creator Spiritus is rarely notated in the extant mission sources, a sheet in choirbook C-C-68:2 at the Bancroft Library sheds considerable light on how the piece was executed under normal circumstances and, in contrast, how Serra and Palóu had to shift their expectations in the first days of the mission period. ${ }^{7}$ A careful examination of the melody shows it to be very closely modeled on the "standard" Gregorian melody of the Roman rite (dating from around the ninth century). ${ }^{8}$ Each of the odd-numbered verses has the well-known tune notated above the appropriate lines of text, but all of the evennumbered lines are written out as text alone. The California source unmistakably implies that an alternatim performance style is required, in which two different textures or styles alternate back and forth. Here, the standard tune is utilized for the odd-numbered stanzas, and some other style (probably a more complex setting in canto figurado or canto de órgano) cradles the text for the even-numbered stanzas. ${ }^{9}$ If we are to use the California settings of other semistrophic pieces as a model-for instance, the renditions of Veni Sancte Spiritus, Dies irae, Lauda Sion Salvatorem, Victimae Paschali laudes, Vexilla Regis-then we can gather that there was an alternation between contrasting textures corresponding to the odd- and even-numbered verses. ${ }^{10}$ In the case of Veni Creator Spiritus, the standard melody is realized as canto llano; the opposing phrases would be drawn from a contrasting texture, accompanied by instruments. When Serra and Palóu founded the San Fernando Mission 
in Baja California, however, they did not have an organ, or any other instruments, readily available-so they probably had to perform Veni Creator Spiritus not as a juxtaposition of different performance styles but as a repeated realization of the stanzas in plainchant with no recourse to instrumental accompaniment.

\section{Serra and the Founding of San Carlos Borromeo near Monterey}

A little over six weeks after the makeshift ceremony at San Fernando in Baja California, Padre Serra and his fellow missionaries-along with the military commander, Gaspar Portolá, and his soldiers-trudged the final miles up from Vellicatá to arrive in San Diego in the new region of Alta California. This ragtag group of about seventy men fully expected to arrive at an already established base camp and fortifications, for according to the plan that had been hammered out before departure, two ships were to sail from Baja California with provisions and troops who were to build the initial structures and prepare for Serra's arrival. But misfortune and mishap afflicted the voyages of both the San Carlos, which set forth from La Paz, Baja California, in January 1769, and the San Antonio, which sailed the following month. Both ships were blown off course and suffered a litany of adversities: by the time the ships arrived in San Diego, the crews were suffering from abysmal health and disease. Ninety men had manned the ships when they left port; only sixteen arrived in good health. One can only imagine the distress of Serra and company when they first caught sight of their comrades: they expected to find the beginnings of a new settlement and encountered instead more graves than reinforcements. Not surprisingly, then, neither Serra nor his biographer Palóu provides a detailed account of the opulent ceremony that they had expected for the founding of the mission at San Diego-the padres were more concerned with the urgent necessities of stabilizing a very perilous and tenuous situation than with putting together an impressive pageant to attract new converts. ${ }^{11}$

In contrast, conditions had stabilized enough within the year that, by the time of the founding of the next mission, San Carlos Borromeo de Carmelo near Monterey (also referred to simply as the Carmel Mission), a full-blown spectacle was planned for its inauguration on 3 June 1770 (Figure 1).

In a letter to Father Juan Andrés, Serra renders a vivid account of the day's happenings in all their theatrical pageantry and splendor. Clearly, the intended audience was not confined to the friars and servicemen in attendance; the spectacle simultaneously was meant to attract 


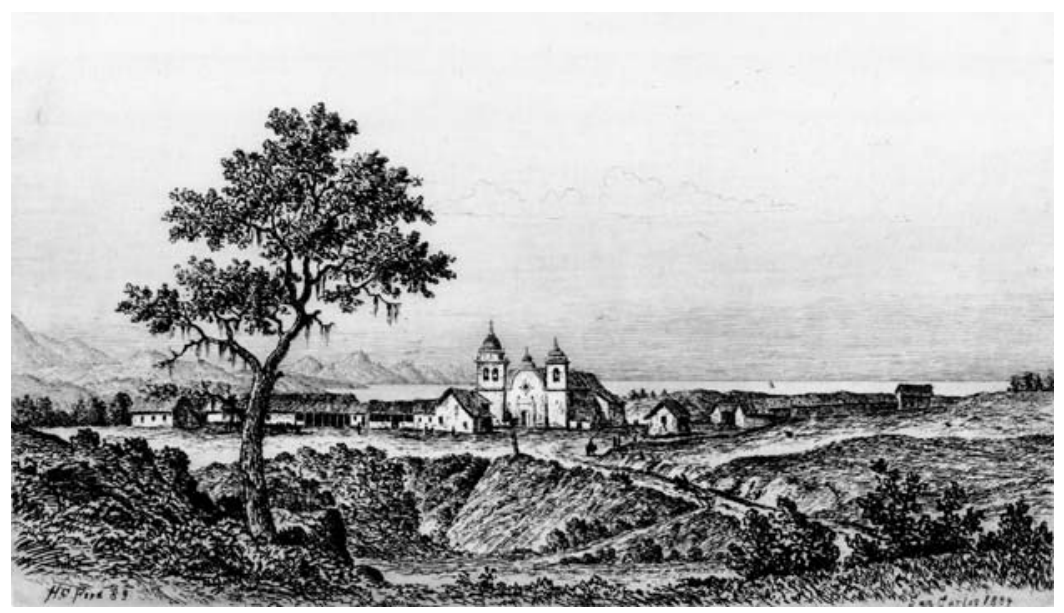

Figure 1. Carmel Mission ("View of San Carlos Borromeo Mission") (1883), by Henry Chapman Ford. Bancroft Library, BANC PIC 1963.002:0917:18-ffAL. Photo courtesy of the Bancroft Library, University of California, Berkeley. Pictures found in the Online Archive of California (OAC). http://content.cdlib.org/ark:/13030/ tf 5 j49p2cz/?brand $=$ oac

and impress the Native Americans who would have been watching the peculiar assemblage that had ventured onto their shores. In his letter of 12 June Serra delineates in minute detail each of the events:

The day came. A little chapel and altar were erected in that little valley, and under the same live oak, close to the beach, where, it is said, Mass was celebrated at the beginning of the last century. We came to the same spot at the same time from different directions, those from the sea and those from the land; we were singing the divine praises in the launch, and the men on land, in their hearts.

Our arrival was greeted by the joyful sound of the bells suspended from the branches of the oak tree. Everything being in readiness, and having put on alb and stole, and kneeling down with all the men before the altar, I intoned the hymn Veni Creator Spiritus at the conclusion of which, and after invoking the help of the Holy Spirit on everything we were about to perform, I blessed the salt and the water. Then we all made our way to a gigantic cross which was all in readiness and lying on the ground. With everyone lending a hand we set it in an upright position. I sang the prayers for its blessing. We set it in the ground and then, with all the tenderness of our hearts, we venerated it. I sprinkled with holy water all the fields around. And thus, after raising aloft the standard of the King of Heaven, we unfurled the flags of our Catholic Monarch likewise. As we raised each one of them, we shouted at the top of our 
voices: "Long live the Faith! Long live the King!" All the time the bells were ringing, and our rifles were being fired, and from the boat came the thunder of the big guns.

Then we buried at the foot of the cross a dead sailor, a caulker, the only one to die during this second expedition.

With that ceremony over, I began the high Mass, with a sermon after the Gospel; and, as long as the Mass lasted, it was accompanied with many salvos of cannon. After taking off my chasuble after Mass, all together we sang the Salve in Spanish in front of the wonderful painting of Our Lady, which was on the altar. The Most Illustrious Inspector General had given us the picture for the celebration, but with the obligation of returning it to him afterward, as I will do when the boat sails.

As a conclusion to the liturgical celebration, standing up I intoned the Te Deum Laudamus; we sang it slowly, and solemnly, right to the end, with the verses and prayers to the Most Holy Trinity, to Our Lady, to the Most Holy Saint Joseph, patron of the expedition, to San Carlos, patron of this port, presidio and mission, and finally the prayer of thanksgiving. ${ }^{12}$

Just as we saw outside Vellicatá, Serra folds militaristic pageantry into the singing of mass with the rifle volleys and cannonades from the ships. The effect was meant to cause a ruckus, attract local interest, and perhaps even show off a bit and intimidate the local residents with the display of military might and overwhelming firepower. And we see again the central role of the song Veni Creator Spiritus in the founding of Monterey in 1770, just as at San Fernando near Vellicatá in May 1769. The Carmel Mission, which was to become Serra's home church, possesses a fragment of an extremely old missionary antiphonary with Veni Creator Spiritus. It is tempting to imagine this being a possible source from which Serra and his followers sang at the founding of the Carmel Mission (Figure 2).

The singing of the Salve and Te Deum was part of the daily regimen of Spanish soldiers and sailors ever since the initial contact with the New World. Kristin Dutcher Mann quotes a fascinating account given by Father Juan María Ratkay, a Jesuit, of the sailors' routine on board ship in 1680 - and it included the singing of mass in the morning and observance of the Laurentian Litany and the Salve Regina after sunset. She further delves into Jacob Baegert's account of the Jesuits and other passengers on board ship celebrating mass five times each day, as well as singing the rosary plus the Salve at sunset. On the important Feast Day of Saint Peter and Saint Paul, they further sang the Te Deum during their 1750 voyage. In yet another California celebration involving military personnel, priests, neophytes, and the singing 


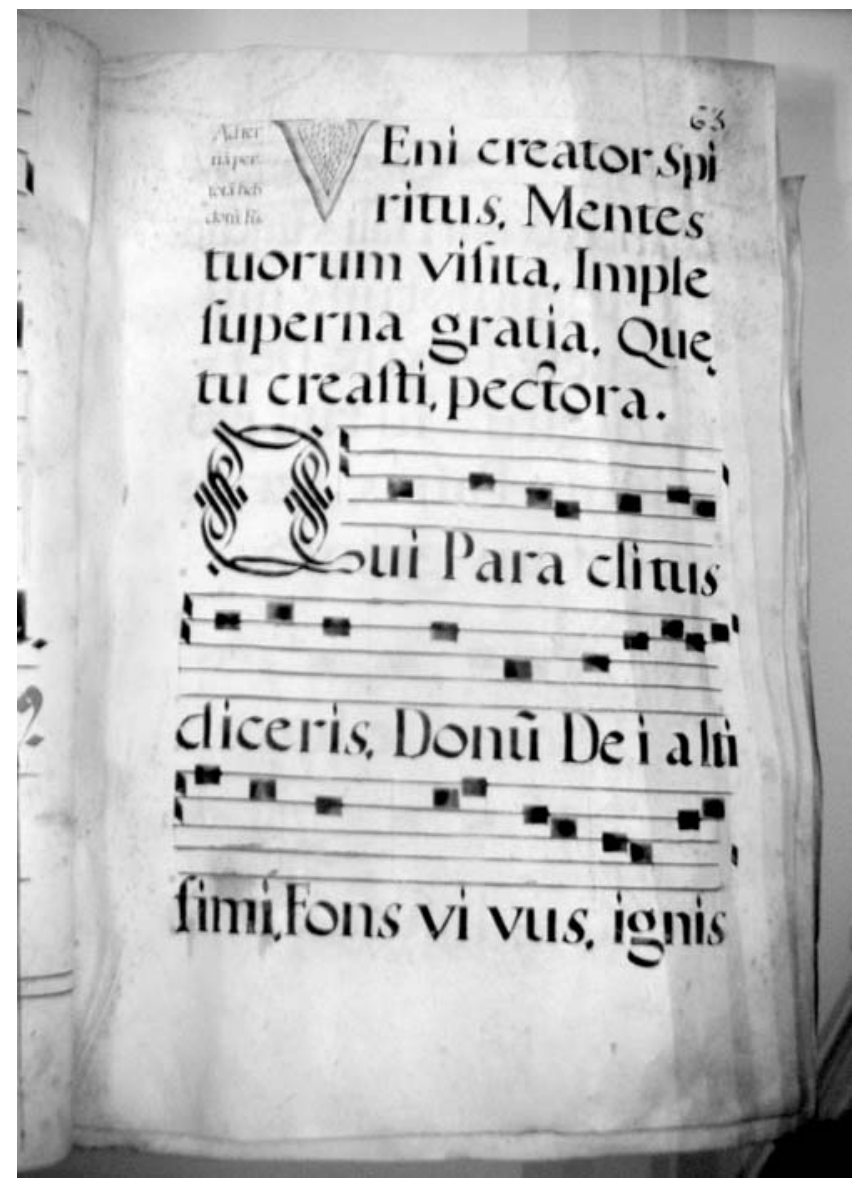

Figure 2. Veni Creator Spiritus, Carmel Mission Ms. 2, "Antiphonary," Ms. 308.1955.46.139, fol. 4. Permission to include image courtesy of Carmel Mission. Photo by the author.

of the Te Deum, we find it incorporated into the festive pageantry at the inauguration of Governor Pablo Vicente de Solá at Monterey in $1815 .{ }^{13}$ In short, Serra's selection of core material was part of a broad and longlasting tradition, not a personalized and idiosyncratic one. ${ }^{14}$

\section{The Salve}

Another piece mentioned by name at the founding of San Carlos Borromeo near Monterey was the Salve, a reference that merits careful scrutiny. Serra recalls that after the singing of mass, "all together we sang the Salve in Spanish in front of the wonderful painting of Our 
Lady, which was on the altar" (cantamos todos la salve en romance ante la bellisima imagen de Nuestra Señora que ocupava el altar). Each detail is noteworthy. First, we are told that it was not Serra himself who sang the piece, nor Serra and a few others-but everyone. Second, we observe that the Salve was not sung at mass but after it, specifically in conjunction with the veneration of the Virgin Mary. Third, Serra reveals that the whole group sang the Salve in the vernacular-in this case, Spanish-not in liturgical Latin as one would expect of typical sacred functions of the period. And last, Serra identifies the work by the abbreviated name, so short that he pruned it to a single word, Salve. In their translations of Serra's text, both Geiger and Tibesar assume the padre was referring to the famous antiphon Salve Regina, one of four antiphons to the Virgin that was performed during the last service of the day, Compline, through the various seasons to encompass the entire church year (the other three tunes being Alma Redemptoris Mater, Ave Regina caelorum, and Regina caeli laetare). ${ }^{15}$

However, this assumption is not explicitly confirmed by Serra, and I would argue that if one adopts this translation, one immediately is confronted by a series of irksome problems. The ancient antiphon Salve Regina is exquisite, but it is lengthy, with no literal repetitions of text or melody to hold one's place. It takes unexpected turns that make memorization a problem for a culture no longer steeped in the oral tradition. How is it that a hodgepodge of soldiers, friars, and neophyte converts from Baja California spontaneously launched into the Salve Regina by memory, with all its treacherous twists and turns, in a language that almost none of them spoke? The severity of the problem is borne out by one of the few extant manuscripts from the mission period that contain the Salve Regina, a loose sheet in Juan Bautista Sancho's handwriting ${ }^{16}$ that presently is found in the archive at the San Fernando Mission; it departs considerably from the standard Gregorian model as found in the plethora of chant books in Europe (see Figure 3 for a facsimile of this sheet). ${ }^{17}$

Furthermore, it varies substantially even from the Franciscan version of the Salve Regina that had developed in the late thirteenth century and then continued with only microscopic variations in the printed Franciscan books of the sixteenth century and beyond. ${ }^{18}$ It is as if Sancho were reminiscing and trying to recall the tune that he had once sung long before but had no "official" written model to help prune out the inadvertent discrepancies that had crept into his individualized version. Sancho was arguably the most accomplished musician of the period and a thoroughly trained Franciscan who would have sung Compline (and the four Marian antiphons) with regularity. If even 


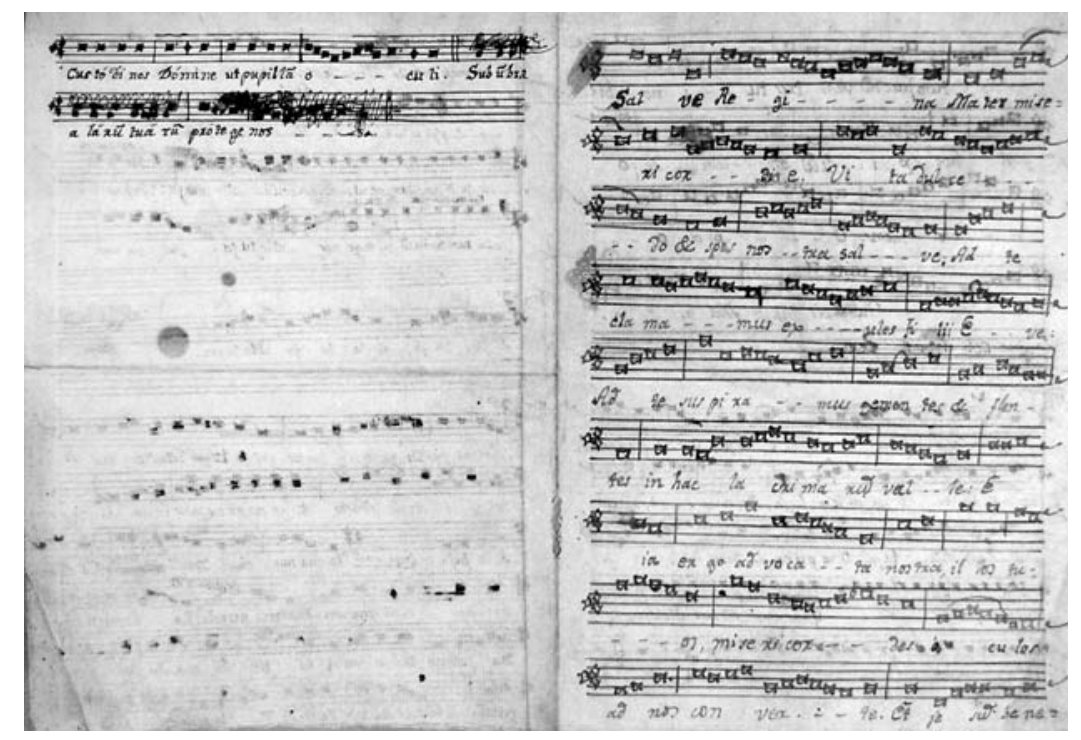

Figure 3. Salve Regina and Compline service, San Fernando Mission, Archival Center of the Archdiocese of Los Angeles, manuscript S-5. Permission to include image courtesy of the ACALA. Photo by the author.

Sancho veered off course in his recollections, how then could a group of soldiers who rarely sang Compline be expected to join in with any accuracy? Of course, it is entirely possible that Sancho is on the mark and is accurately recording the tune from another source, but one that differed in content from what was common. In that case, we are left with the same dilemma. How could this diverse grouping of peoples with radically different backgrounds suddenly have joined together in the singing of a complicated melody if the melodic model for the Franciscan friars was an unorthodox and nonstandardized one?

The other California manuscripts provide scraps of clues that resolve these issues. One of the most commonly found text settings in mission sources is that of "Salve Virgen pura," which—significantly-is a Spanish text, short in duration, and downright catchy. All those features make it a likely candidate for the Salve that Serra described. Narciso Durán neatly records four settings of "Salve Virgen pura," and for each the text is identical: ${ }^{19}$

Salve Virgen pura, Salve Virgen Madre, Salve Virgen bella, Reyna Virgen salve.
Hail, pure Virgin, Hail, Mother-Virgin, Hail, beautiful Virgin, Virgin-Queen, hail! ${ }^{20}$ 
Not only is the text accessible, but in each case the entire musical setting lasts but eight measures in a semipredictable and appealing fourpart harmonization. The rhythmic substructure is also carved out of the same basic pattern. For the three settings in quadruple meter, the core two-measure pattern that surfaces for each phrase and line of text follows the pattern short-short-short-short | long-long. The one setting in triple meter has an equally simple pattern that recurs four times as well, running long-short | long-short | long-short| extra long.

Slight variants of this text and musical setting resurface in other locations, such as San Juan Bautista Ms. 1, on page 111 (plate 130 in WPA item 45). Its lyrics begin, "Dios te salve Reyna Maria" (May God save you, Mary-Queen), and the table of contents identifies this piece by the title "Salve Regina a 4 voces." This same tune and harmonic setting - in an abridged version - appear in an 1803 manuscript from the Convento San Francisco de Tarija in Bolivia, demonstrating that the Franciscans took this setting with them all across the Americas. Its importance in daily life is emphasized by the heading at the top of this musical sheet, which reads: "Salve, que se canta a tres vozes todos los días para dar principio a la Santa Misión" (The Salve that is sung in three-part harmony every day, in order to begin the day at the Holy Mission [of Tarija]). ${ }^{21}$

That the piece was a staple in mission life for well over a century and that it enjoyed fame in the rest of the Hispano-American world is borne out by several documents, such as the program for graduation ceremonies at the Sisters of Charity School in Los Angeles on 25 June 1858. Six sisters (three of whom were Spaniards) had arrived two years earlier, on 6 January 1856, and established a school for their young wards. They formed a choir from the 170 young ladies enrolled at their institution, and we can gather the breadth of their repertoire by the music they sang at their graduation, including such pieces as "Gaude Virgo," "Ave Sanctissima," W. W. Wallace's "It Is Better Far to Speak Softly," W. E. Hickson's "O Come, Come Away," and "Dios te salve María"- the same song that is written out (in a variant form) in San Juan Bautista Ms. 1.22

Yet another document reinforcing the wide dissemination of this song is the Yorba manuscript at the Bancroft Library. ${ }^{23}$ Although written out in 1934, the preface to this volume provides a fascinating account of the booklet's contents and traces the heritage of its material back to recollections of Don Benancio de Ríos, who in 1864 wisely began to scribble down the lyrics to the repertoire of the California missions as they had been taught to him by his aging father, Don Santiago de Ríos, who served as cantor at the San Juan Capistrano Mission from 
around 1840 to $1870 .{ }^{24}$ Although none of the tunes are recorded therein, the Yorba manuscript is particularly useful in reconstructing the complete text of the piece as it was passed down through successive generations in the missions.

There was little variation between the hymns of the time. In the Yorba manuscript, it is not much of a stretch from song number 15, "dios te salbe Maria" (Hail Mary), to song number 18, "dios te salbe bella augrora" [sic] (Hail Mary, beautiful Dawn). Even closer is song number 27; this third example from the genre appears in the table of contents, catalogued as "dios te salbe birgen pura," [sic] whose title departs just a smidgen from the Durán choirbook text for "Salve Virgen pura." The lyrics here, however, are not just a fleeting quatrain as they are in the Durán choirbooks but instead continue for a seemingly endless stream of subsequent stanzas. On the surface, the protracted length of the lyrics would argue against group performance for the reasons already presented; when would a group of gun-toting soldiers have the time to learn and rehearse such a gargantuan text? Fortunately, the engrossing preface to the Yorba manuscript explains exactly how this could be achieved. The head cantor would sing a line of a text, after which the assembled congregation would repeat the text in a subsequent response. Thus, if even one person had committed the whole song to memory and could lead the group through the forest of words, the entire group could wend its way successfully through to the end. The preface to the Yorba manuscript is of inestimable importance, due to its references to the origins of the mission music literature and the richly descriptive detail concerning its performance in daily life. Its opening paragraphs explain as follows:

Origin and History of these ancient chants of Mission San Juan Capistrano / Origen e historia de estos cantos.

All of the chants in this manuscript are in their original form as taught to the indios neófitos of this mission from 1775 to about 1840 by the Franciscan padres.

Many of them were composed in ancient Spain, and some in Mexico after 1530.

Aside from those which the padres themselves chanted during the Rosary, after Mass, \& after requiem Masses for the dead or during the alabanzas for the month of May (such as Bella Augrora [sic], Despedida, E⿱ Benir Pecadores) but which were also chanted by laymen, these chants of praise to the Heavenly beings and songs of the velorios (wakes), (such as Abe Maria Beninísima, En la cria de un ojo de Agua, etc.) were usually led by the official cantor or chanter of the mission. 
The cantor would sing the opening verse, which all present would then repeat. Thereupon he would sing the second verse and so on, each time being answered in unison by the congregation with the chorus.

This custom is still in full effect among the paisanos of San Juan Capistrano, especially at the velorios or wakes, which begin at $8 \mathrm{p} . \mathrm{m}$. and do not end until the singing of the Alba $(l a l b a)$ the following dawn. ${ }^{25}$

It seems reasonable, then, that the performance of the Salve that Serra briefly notes in his letter of 1770 could have been handily achieved by using the model described in the Yorba preface and by the musical snippets that were certainly known in the various California missions, at least in the early 1800 s and probably earlier. A simple eight-measure loop (such as those in the Durán choirbooks) could have been repeated over and over to accommodate a lengthy Salve text in Castilian, such as those in the Yorba manuscript. At the founding of Monterey and the San Carlos Borromeo de Carmelo Mission in June 1770, either Serra or some other friar with a good ear and capable memory could have offered each line of text, in the same way that pastors "line-out" spirituals or gospel tunes in African American churches in the South. Just as the call-and-response singing of the American South allowed "regular" folks (not just conservatory-trained experts) to participate in a profoundly rewarding musical experience, so the songs from early California resounded with similar musical strains. In this repertoire described by Serra and clarified by the later Franciscan documents, we discover friars, soldiers, and neophyte converts joining together in a singing tradition where a worthy tune, a good cantor, and the simple practice of following the leader made congregational singing a practicality instead of an impossible obstacle.

Pedro Cabot writes out an even simpler, more utilitarian rendition of the Salve in Santa Barbara Mission Doc. 4B. Cabot's elegant and very precise handwriting records the lengthy text, the three voices sharing a single staff, but there are only two musical phrases that serve as the core material from start to finish. They are actually more intonation formulas than "composed melodies," since the opening harmony can be reiterated multiple times as needed to accommodate extra syllables in any particular line. The rather static nature of the phrases and the circling back over familiar musical territory in seemingly endless loops would make this setting a prime candidate for the Salve that was passed by word of mouth among sailors, soldiers, neophyte converts, ranchers, and other Californians who learned their music through the oral tradition, not erudite notation that required extensive training to read and understand. 
Yet another rendition of the Salve crops up in California sources, and its setting is much more user-friendly than the plainchant version found in the Liber Usualis. Santa Clara Ms. 3 records a folklike melody in canto figurado style; it marches forward in a sturdy duple meter in the key of $\mathrm{A}$ minor. ${ }^{26}$ Its notation is approximate, not rigorous, and quite a bit of rhythmic fudging is necessary, with respect to note values, to ensure that there are not distracting hiccups or truncations in certain measures. Although its stolid character makes it inherently appealing, its length and lack of melodic phrase repetitions make it an unlikely candidate for the Salve performed at the founding of Monterey. In addition, its Latin text disqualifies it from consideration, since Serra clearly states it was in the vernacular.

\section{The Te Deum}

A few further comments concerning Serra's description of the founding of Monterey are in order. He concludes his brief portrait of the day's ceremonies with a reference to the Te Deum, some litanies, and a "song of thanksgiving." The Te Deum, also known as the Song of Ambrose and Augustine or the Hymn of Thanksgiving, was one of the staples of Catholic liturgy and was of great importance as the concluding piece of a Matins service. In Mexico, in fact, the Te Deum would have been one of the most beloved and well-known selections in religious performance, since Matins was as important in New Spain as opera was in baroque Naples or oratorio in baroque England. Matins, in truth, was the primary form of large-scale spectacle and entertainment in baroque Mexico. ${ }^{27}$ In this context, it is not surprising to see it occupy an equally critical place in the pageantry and ceremonial spectacle of the California missions.

In fact, even in the earliest days of California's mission period, the Te Deum was sung on almost any occasion of great joy and celebration. When the overland De Anza expedition eventually reached its California destinations in 1776, the ecstatic friars welcomed their friends with the exuberant singing of the Te Deum. Concerning their arrival at San Luis Obispo, we are told,

Too excited and eager to await its slow pace, Fathers Caballer and Mugártegui went out on the road to meet the caravan. On its arrival Father Figuer, vested with a cope, bearing a censer, and with a broad smile on his face, was awaiting the pilgrims at the church door. Amid peals of mission bells and volleys of musketry the whole colony entered the temple chanting the Te Deum, "and thus our arrival was a matter of great and mutual joy." 28 
Similarly, the de Anza party's arrival at Monterey was met with festive celebration. Pedro Font's diary entry for 11 March 1776 reads:

The Commander and I and some few others set out for the presidio of Monterey at four in the afternoon and, at five, arrived at the Mission San Carlos de Carmelo-marked on the map with the letter G-having traveled one long league southwest by south. Here the fathers-there were seven of them-received us, singing the Te Deum, with the peals of bells, and great rejoicing. ${ }^{29}$

In Serra's account of the founding of Monterey, he too recalls how he intoned the Te Deum, and he implies that the assembled friars (and maybe soldiers) participated in the singing as well. He recounts, "As a conclusion to the liturgical celebration, standing up I intoned the Te Deum Laudamus; we sang it slowly, and solemnly, right to the end."30

Where are the music sources that might clarify what notes Serra and his Franciscan brethren sang? If we are to consider the various extant settings for the Te Deum in the California sources, we find considerable variety in style and performance practice, and most of them would have been practical for realization in the context of this propitious day in 1770 . The monophonic version that seems most consistent with the common Te Deum that had been used for centuries is the one recorded in Santa Clara Ms. 3. ${ }^{31}$ It is not so much "melodic" as formulaic, with repeated notes for the bulk of a textual line and then a handful of recurring melodic gestures that are used to close off the various verses. It is not unlike the two formulas for the Te Deum found in the Liber Usualis - the "Solemn Tone" formula and the "Simple Tone." 32 Interestingly, the California manuscript is a combination of the "Solemn Tone" and the "Simple Tone" rather than being a pure and discrete version of one or the other. The repetitive aspect of intoning formulas would have made performance by Serra's entourage a snap. A few performance cues are suggested by the notation as well. The sudden shift to text in all capital letters at the section "TE ERGO QUAE SUMUS ... SANGUINE REDEMISTI” corresponds to the portion of the Te Deum where the participants are expected to kneel. ${ }^{33}$ As the singers removed themselves back to their seats or to a standing position, the text itself resumes normal capitalization procedures where only the first word of a phrase receives a capital letter.

Another more luxuriant but equally plausible candidate for the Te Deum as heard in 1770 is the "Te Deum for Four Voices in the Fifth Tone and the Fourth Tone (Te Deum a 4 Vs $5^{\mathrm{o}}$ y $4^{\mathrm{o}} \mathrm{T}^{\mathrm{o}}$ )" " recorded in 
multiple California manuscripts, including versions written out by Father Narciso Durán (see Figure 4). ${ }^{34}$

As the title states, the Te Deum is harmonized for four voices, but as we have seen in the polyphonic Psalm-tone formulas at the missions, this is similarly a series of chords in a formulaic pattern that allows the vocalists to sing in a fluid, speechlike rhythm and simply pour in the appropriate text. The harmonic mold is infinitely flexible, capable of accommodating the many varied lines of the Te Deum (in exactly the same way that the monophonic formula of Santa Clara Ms. 3 works wonderfully in adapting to the mercurial changes in the text patterns). The Durán version only includes the text for the odd-numbered verses. We can safely assume that this is yet another example of alternatim technique in which the odd-numbered verses are sung in the free-flowing rhythm of fauxbourdon in polyphony, while the even-numbered verses are sung in another texture altogether, probably in intoned plainchantsuch as the monophonic formulas and text found in Santa Clara Ms. 3-or in instrument interpolations that take the place of the excerpted verses. At the top of the page, Durán has written, "Vt y de La" (In C and in A) to facilitate finding instrumental passages in the key of $\mathrm{C}$ major or A minor that could then serve as appropriate substitutions

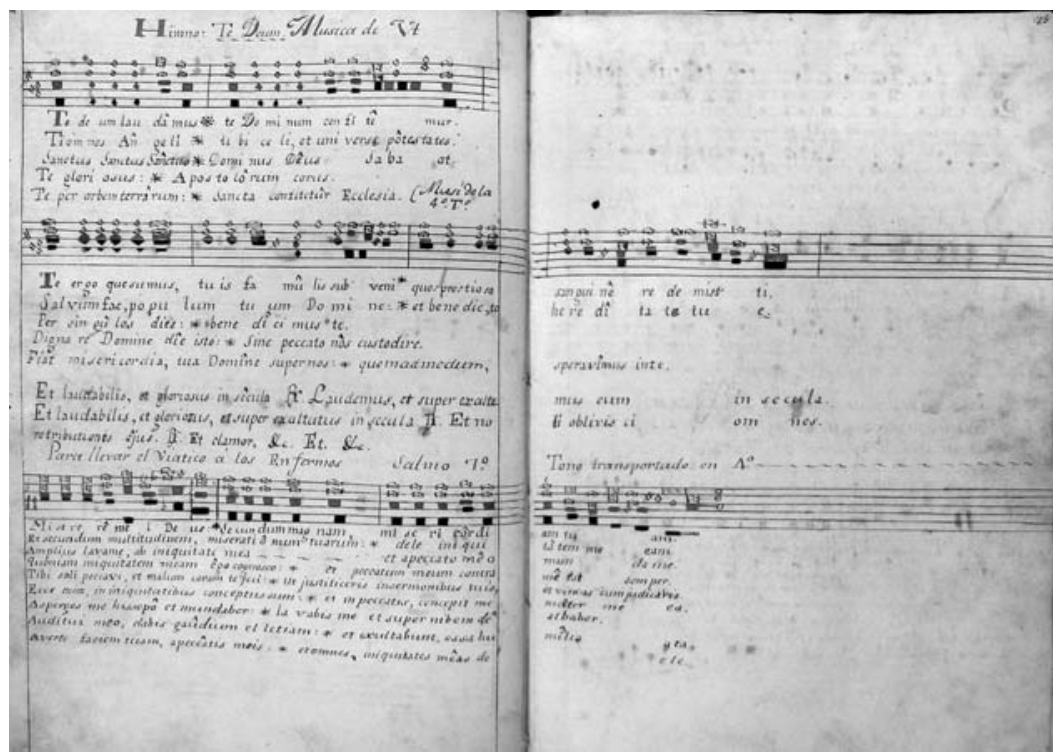

Figure 4. Te Deum (intoned in polyphony), Santa Barbara Mission Archive-Library, Document 2 (Choir Book from the San Rafael Mission), pp. 84 and 85. Permission to include image courtesy of the SBMAL. Photo by the author. 
for the even-numbered phrases without any jolting harmonic surprises. Like the Santa Clara Ms. 3 that had a visual cue of the division point where the performers knelt, so too does the Durán Te Deum have a structural division at the point where the believers would genuflect before God. At the line "Te ergo quae sumus," the old harmonic formula is discarded and a new one takes its place; it then is used as the mold for the subsequent phrases up through the end of the piece.

Yet another intriguing Te Deum surfaces in the Sancho materials in folder 77 of the WPA collection at the University of California at Berkeley, with the title page stating "Te Deum for Four Voices Alternating with the Voices of the Choir" (Te Deum a 4 voces alternando con las del coro) and immediately below it another subtitle, "Te Deum for Four Parts for the Use of Friar Jayme Pou. This passed into the possession of Father Friar Juan Bautista Sancho" (Te Deum â 4 del uso de Fr. Jayme Pou. / pasó al uso del Pe Fr. juan Bau[tis]ta / Sancho). ${ }^{35}$ The folder contains four sheets for the four solo voices: soprano, alto, tenor, and bass. All phrases are in quadruple meter and strongly in mode 6 (as stated on the bass part), with a modern-sounding feeling in the key of $F$ major. Whereas the other Te Deum versions we have considered set the odd-numbered verses, this particular rendition in WPA fol. 77 has brief phrases, each slightly different from one another, that progressively wind through the even-numbered verses. As we have seen previously, polyphony was often performed one on a part in California mass settings, while the choir as a whole joined together for the monophonic canto llano or homophonic passages in canto figurado. Neither the intoned formula of Santa Clara Ms. 3 nor the four-part fauxbourdon versions of the Te Deum already discussed make very compatible companions for the phrases in WPA fol. 77; although the folder's even-numbered verses could be smoothly folded into the creases of the odd-numbered verses in the other Te Deum settings, their modes, or "keys," are not really compatible. ${ }^{36}$

\section{The Alabado}

The last piece that Serra includes at the founding of San Carlos Borromeo de Carmelo was the acción de gracias, or "prayer of thanksgiving." Although not mentioned by its most common name, it is probably the beloved alabado (song of praise) that was one of the most widespread genres of the period across Latin America. Upon rising at daybreak or retiring at dusk, no piece was more central to daily life in California than the alabado. The first recording of an alabado was made at the turn of the twentieth century by Father Alexander Buckler of Fernando 
Cárdenas of the Santa Inés Mission, better known by his nickname, "Fernandito," when the singer was eighty-four. Charles Francis Saunders and J. Smeaton Chase describe the recording as metrically fluid and not at all regular-but it is hard to know whether it is a characteristic of the song itself or merely reflects the liberties taken by an octogenarian singer. ${ }^{37}$

Father Owen da Silva writes an engaging summary of the alabado and provides critical information regarding the circumstances of the Fernandito recording. Da Silva states,

Foremost among the old hymns is this one, the Alabado. It is mentioned in almost every historic account of California and the Southwest. It was sung by padre and soldier, colonist and neophyte, in church, at home, in the field, and on the trail. The padres often used it in place of the Te Deum.

The hymn consists of twenty-four stanzas praising the Holy Trinity, the Blessed Sacrament, the Virgin Mary, the Angels and Saints....

From Father Font we know that the Alabado was sung to the same tune at all the Missions. We believe that the present version [that da Silva prints in his volume] is the one referred to by that exact padre, and therefore, the original one. The late J. Smeaton Chase recorded it at Mission Santa Inés more than twenty-five years ago. The singer was Fernandito. We have also heard an old Edison home recording of Fernandito singing the Alabado at the home of Miss Mamie Goulet in Santa Bárbara. Miss Goulet and her uncle, the Rev. Alexander Buckler, were custodians of Old Mission Santa Inés for many years, and shortly before Fernandito's death in 1919, Miss Goulet was happily inspired to record the voice of the last of the Mission singers. ${ }^{38}$

One enigmatic segment of an alabado appears in the Sancho materials of the WPA collection at the University of California at Berkeley. ${ }^{39}$ The entire folio is a mishmash of musical ingredients, almost all of them small and fragmentary. This particular tidbit is written in the bass clef in triple meter in the key of F major; the five measures are written at the bottom of the page and upside down from the rest of the sheet's music (except for another brief excursion, "O dulcisimo jesu yo te doy mi corazon," on line 7). Its tune bears no perceptible relationship to the melody as sung by Fernandito and subsequently notated by da Silva, nor the tune indicated by Robert Stevenson or by Saunders and Chase. ${ }^{40} \mathrm{At}$ one point in time there had been an alabado in a choirbook at the San Juan Bautista Mission, but the book apparently has been lost, making it 
frustratingly impossible to compare it with the other notated versions of the alabado. ${ }^{41}$

In all of the Hispano-American world, the alabado was as much a part of daily life as sunrise or sunset. Leonardo Waisman's research on the Chiquitos missions of Paraguay during the eighteenth century demonstrates that the alabado and rosary were sung an hour before sunset at the evening service. ${ }^{42}$ Philipp Segesser von Brunegg describes nearly the same tradition as practiced in Sonora and Arizona in the first half of the eighteenth century, clarifying that the end of the day was marked by the singing of the Salve Regina, the rosary, the litany, and the alabado. ${ }^{43}$ Texas, too, was part of this universal practice in the Hispano-American world. John Koegel informs us that the priest at Nuestra Señora del Rosario de los Cujanes (located near Goliad on the Gulf of Mexico in Texas) would call the converts together on Saturdays and lead them in reciting the rosary and singing the alabado. ${ }^{44}$ Its popularity in that region has been long lived. Anna Blanche McGill, writing in 1938, affirms that the alabado and alabanza were still sung throughout Texas and the American Southwest. ${ }^{45}$ Kristin Dutcher Mann provides a panoramic view of the alabado's usage, taking us to Dolores Mission in Sonora in 1687 and later presenting a strong case linking Fray Antonio Margil de Jesús's alabado from the early 1700 s with the one brought to California by Pedro Font and the de Anza expedition. ${ }^{46}$ John Donald Robb, Thomas J. Steele, Vicente T. Mendoza, and Virginia R. R. de Mendoza also explore the alabados that permeated the folkloric cultures of Mexico and New Mexico. Unfortunately, there is no irrefutable proof that would link the texts and tunes collected by Robb and Mendoza to mission-period California. Nevertheless, it is quite possible that some of the versions that Robb and the Mendozas collected were transmitted to Alta California through the oral tradition, even though they left no solid paper trail. ${ }^{47}$

In the missions of Baja California, the alabado was sung several times at key moments of the day. ${ }^{48}$ Using the writings of Miguel de Barco as source material, Harry Crosby details the ritual and regimen of daily events as they unfolded each day at the San José de Comandú Mission. From the rising of the sun until dusk, the alabado was the most common recurring element marking the key points of the day, as Crosby relates:

As the neophytes entered [the church after rising], they broke up and sat in four separate groups: men, women, boys, and girls. They joined in prayer and proclaimed the Blessed Virgin. The Alabado was sung, first by men, then by women, then by both. Singing was led by two neophyte 
women, Inés and Chepa, designated as cantoras (singers) and picked for strong voices and musical ability. At other times, the cantoras probably helped in teaching the young to sing.

Worshippers whose work was needed to start the mission day rose from devotions and began their chores .... People who had no immediate duties stayed in church and took part in the daily Mass. That finished, they said prayers, sang the Alabado again, and went to take breakfast. ${ }^{49}$

Crosby then explores the various chores and tasks that kept the men and women occupied after breakfast and continues by describing the schooling of the children in sacred instruction, including the singing of the alabado yet again:

At ten in the morning, the sexton again tolled the bells, and the boys and girls who were being prepared for catechism went to church.

Segregated by sex, they chanted the catechism in unison, they sang the Alabado, which they were bade to perform "with proper feeling."

At midday, the bell was sounded anew, and all knelt, prayed to the Virgin, and sang the Alabado one time through. Then a noon meal was dished out.... After the meal, everyone took a siesta until the hour of two, then work resumed. At five, the bell was tolled, and boys and girls again went to church to recite the Angelus and the catechism. At the end, they took turns singing the Alabado. ${ }^{50}$

The schedule as told by Miguel de Barco is reconfirmed by other writers familiar with activities in the Baja California missions. Father Sebastián Sistiaga captures the events of mission life at San Ignacio, Baja California, in 1744: "Daily, on arising, which is quite early, they direct their thoughts to Jesus Christ and His Most Blessed mother by singing the Alabado that the Spaniards recite." ${ }^{51}$ Father Nicolás Tamaral relates the day's conclusion, a ritual that we have seen described by the other writers of the time:

After eating [the evening supper], all go to the church and, with the padre, recite the invocation and responses of the Rosary and Litany. This is done then and not before, because everyone is free of duties and able to pay full attention to his most important devotions. After chanting the Rosary and singing the Alabado in the church, all leave; the men with their temastián and the women with their temastiana, to totally separate places where they practice the catechism and then retire. ${ }^{52}$

Alta California was no different. Upon Serra's arrival in this new frontier, the alabado was one of the first pieces he would teach at each new outpost. 
He taught this popular gem to the neophytes at the San Gabriel Mission in the 1770s, and Engelhardt tells us that as early as September 1773 the Native Americans at Rincón had learned the tune from Serra and his brethren..$^{53}$ Other padres taught the alabado to new converts with equal vigor. The Franciscan Chronicler (writing between 1844 and 1850) explains that the alabado, as it was sung at the Santa Inés Mission, had been taught to the neophytes at the Santa Barbara Mission by Father Lasuén. ${ }^{54}$ Father Tapís also considered the work to be essential repertoire, as is evidenced by the multiple copies that exist in his hand. ${ }^{55}$

In one of the most graphic accounts of an early encounter between the Spanish newcomers and the native Californians, the chaplain on the San Carlos, Vicente de Santa María, details the various events of 23 August 1775, as the members of the ship and the Huimen and Huchiun peoples of the San Francisco Bay exchanged songs, dances, and ideas. ${ }^{56}$ As with Serra's approach to first encounters, so the crew of the San Carlos used the attractive and theologically grounded aspects of the alabado to begin the attempt at conversion. He writes:

Two reed boats were seen approaching in which were five Indians. As soon as the Captain was informed of this, he directed that signs be made inviting them aboard, to which they promptly responded by coming, which was what they wanted to do. Leaving their boats, they climbed aboard fearlessly. They were in great delight, marveling at the structure of the ship, their eyes fixed most of all on the rigging.... But what most captivated and pleased them was the sound of the ship's bell, which was purposely ordered to be struck so we could see what effect it had on ears that had never heard it. It pleased the Indians so much that while they were on board they went up to it from time to time to sound it themselves.... Throughout the time the Indians were on board, we tried to attract them to Christian practices, now having them cross themselves or getting them to repeat the Pater Noster and Ave María, now chanting the Alabado, which they followed so distinctly that it was astonishing with what facility they pronounced the Spanish. ${ }^{57}$

Immediately following the Spaniards' singing of the alabado, the Native Americans responded to the artistic gift with their own cultural offering. Vicente de Santa María tells us of the chief's dancing on the ship's deck and reveals his own insatiable curiosity in trying to learn as many Huimen and Huchiun words as he could from the afternoon's adventures. He continues: 
The Indian chieftain, less reserved than the others, showed how ... pleased he was at our warmth of feeling; more than once he took to dancing and singing on the deckhouse. I paid close attention to their utterances that correspond with their actions that their language went like this: pire means, in our language "sit down"; intomene, "what is your name?"

The Franciscan chaplain continues with his thorough recollections of the days that followed; on one occasion he sails to shore in the launch in order to continue his developing relationship with the native residents and to delve further into their language and customs. On shore, the friar and native peoples once again exchange songs and dancing; interestingly, when Vicente de Santa María is asked to sing a song, it is the alabado that comes to mind for the chaplain's performance. He depicts the scene by explaining as follows:

As the Indians remained seated on the shore I could not bear to lose the rest of the afternoon when I might be communicating with them; so, setting out in the dugout, I landed and remained alone with the eight Indians so that I might communicate with them in greater peace. The dugout went back to the ship, and at the same time they all crowded around me and, sitting by me, began to sing with an accompaniment of two rattles that they had brought with them. As they finished the song, all of them were shedding tears, which I wondered at for not knowing the reason. When they were through singing, they handed me the rattles and, by signs, asked me also to sing. I took the rattles and, to please them, began to sing them the Alabado (although they would not understand it), to which they were most attentive and indicated that it pleased them. ${ }^{59}$

The fact that Vicente de Santa María could fit the alabado into the steady rhythmic beat of the rattles implies a regularity of pulse and probably meter that is not evident in the elastic and irregular aspects of the Fernandito recording.

The rosary is not nearly as prevalent in written sources as the alabado, but that is largely the result of its life as part of an oral tradition rather than a written one. Nevertheless, a particularly beautiful setting of the rosary appears on the final pages of Santa Barbara Document 1 and of the San Juan Bautista Manuscript 2, arranged for four voices, in colored notation on a single staff — as is so typical of the California polyphonic repertoire. A single voice initiates the piece with the opening phrase "Dios te salve Maria," after which the other voices chime in at 
"llena eres de gracia." The gentle pulsation in quadruple meter makes it an easily memorized and fetching gem. ${ }^{60}$

That the alabado and rosary retained their importance in the daily routine of mission, rancho, and pueblo life in Alta California is well documented, beginning with Serra's and Palóu's descriptions of the founding ceremonies at each new mission and continuing up through the recollections of Antonio Coronel almost a century later. Palóu describes Serra's weekly habits in his History of the Life and Apostolic Works of the Venerable Father Friar Junipero Serra, indicating the alabado and the recitation of the Crown of the Immaculate Conception of Blessed Virgin (i.e., the rosary) were on the agenda every afternoon (at least during Lent, and Palóu may even imply that it was the expectation throughout the liturgical year). Palóu states, "Every Sunday during Lent he did not content himself solely with the doctrinal discussion during High Mass, but instead during the afternoon after the recitation of the Crown of the Immaculate Conception of the Blessed Virgin and the singing of the Alabado, he preached for them a moral sermon." ${ }^{61}$ Paló alludes to the critical role the alabado occupied in Serra's activities during the Feast of the Immaculate Conception. Once again, the reciting of the rosary and the singing of the alabado are conjoined in the same celebration:

The introduction to the devotion of Our Lady, Mother Mary-and especially with respect to her Immaculate Conception — was dedicated with the same care, especially making ready for celebrating her with the nine-day devotion, which the entire town attended. In addition, the Mass was sung on the day of this great festival, and he [Serra] preached the sermon, and afterward the Gozos [or sung poems] in honor of the Immaculate Conception were intoned. Every Sunday in the afternoon the Crown of the Mother of Mercy was said, finishing it with the alabado and the poems of praise that were sung. And to better honor these praises, the Reverend Father placed an order from Mexico for a stunning statue of the most tender Lady, placed on her platform, they paraded her through the town every Saturday evening, illuminated by lanterns while singing the Crown of Our Lady. ${ }^{62}$

Palóu's last statement highlights the importance of Marian processions on Saturday; the Hispano-American world had long celebrated mass in honor of the Blessed Virgin on Saturdays, and California was simply another outpost venerating this Marian tradition. ${ }^{63}$

Engelhardt's description of activities at the San Antonio Mission corroborates this pattern of a typical day with the reverberating strains of the alabado and Salve-following the same regimen described by Serra 
and Palóu. After dawn, all would gather in the church, recite the doctrine, and sing mass. Then each neophyte and friar would go to his respective chores. At day's end, the bell was rung to announce the reconvening of all at the church, where they would sing the Salve and the alabado. ${ }^{64}$ Chroniclers of later life in California, such as Alfred Robinson and José del Carmen Lugo, reveal that whether californianos were on the rancho or in the mission, the day's activities customarily drew to a close through the veneration of Mary. ${ }^{65}$ The practice that Serra and his fellow friars had introduced in 1769 with the singing of the alabado and the Salve, accompanied with the reciting of the rosary, continued without interruption even through the turmoil and uncertainties of secularization and the Mexican period of the 1830s and 1840s. In his Tales of California, Antonio Coronel tells the reader of the family routine of singing the alabado "in chorus" each morning, and other sacred hymns throughout the day:

Religious education was observed in all homes. Before dawn each morning, a hymn of praise [i.e., the alabado] was sung in chorus; at noon, prayers; at about 6:00 p.m. and before going to bed, a Rosary and another hymn [likely the Salve]. I saw this on several occasions at balls or dances when the clock struck eight: the father of the family stopped the music and said the Rosary with the guests, after which the party continued. I saw the same thing sometimes at roundups, when the old men stopped work to pray at the accustomed hours, joined by all present. ${ }^{66}$

\section{Alba (and Alabanza)}

Yet another work closely related to the alabado, serving more or less as a kind of substitute during the morning routine, is the alba or dawn song. Ever since Owen da Silva's publication of the Alba in 1941, its beguiling melody and lyrics have made it one of the most often recorded and performed compositions from the mission period. ${ }^{67}$ Although da Silva lops off the text after four stanzas, the invaluable Yorba manuscript preserves a total of twelve. When Don Benancio de Ríos wrote down the lyrics as recited to him by his old father, Santiago de Ríos, in 1864, in many instances he captured the sound of the words and syllables but misspelled or misunderstood the actual text. ${ }^{68}$ De Ríos describes the singing of velorios or wakes that consume the entire night with music making until the rising of the sun and the singing of the alba. ${ }^{69}$

So, what did the music sound like? Serendipitously, Ramón Yorba sang "El Alba" for Mrs. W. G. Hubbard, and that tune was subsequently published by Charles Francis Saunders and Father St. John O'Sullivan 
in their rather sentimental but informative Capistrano Nights: Tales of a California Mission Town. Between the lyrics (found in the Yorba manuscript at the Bancroft Library) and the tune (Ramón Yorba's tune found in Capistrano Nights), we have the critical elements for a convincing reconstruction of the alabado as sung in the California missions. ${ }^{70}$

Saunders and O'Sullivan also tell of the Alba's strains that filled the air on any given morning in California's missions and towns. They provide several accounts of elderly Californians who remembered singing the Alba when they were tiny children earlier in the nineteenth century:

Doña Balbineda, who was born here in the mission building, says that her mother remembered how the rough voices of the soldiers in the cuartel, or guardhouse, could be heard joining in it just as day broke; and Doña María has told me that when she was just a little girl on her father's ranch, it was the practice of the family to sing it every weekday morning muy temprano, as she expressed it, very early. At the first sign of light her father's voice resounded through the house, calling, "Levántense, muchachos, y asiéntense á rezar-rise, children, and sit up to pray!” Thereupon all the family would sit up in bed and repeat the angelus-el angel del Señor anunció a María — and as soon as this was concluded the Alba was started. There was no getting out of it; if any did not awake, they were made to awake; and the little María, who was the baby of the family, would thrust her head back into the pillow, immediately prayer and song were ended, for another nap. ${ }^{71}$

Yet another moving account of this tradition is told by Don Antonio Colonel to Mrs. Helen Hunt Jackson, who published his recollections in 1883. Don Antonio ruminates:

It was the custom of the town [Los Angeles] in all of the families of the early settlers, for the oldest member of the family-oftenest it was grandfather or grandmother-to rise every morning at the rising of the morning star and at once to strike up a hymn. At the first note every person in the house would rise, or sit up in bed and join in the song. From house to house, street to street, the singing spread; and the volume of musical sound swelled, until it was as if the whole town sang. ${ }^{72}$

Ms. Jackson further explains that the Cántico del Alba (Morning Hymn to Mary) and alabado "were heard everywhere in California, in mission enclosures, from the courtyards of the ranchos, and in the streets of village and pueblo." She equates the Cántico del Alba with the "Morning Hymn to Mary." Saunders and O'Sullivan have a slightly different tack, equating the alabanza (not the alba) with the "Praises of Mary." In short, many of these terms (alabado, alabanza, Alba, Salve) appear to 
have areas of overlap. In all of these, short melodies repeat to wind their way through a dozen or more stanzas. Alternatim performance would have provided an opportunity for varied sonorities. One of the priests told Saunders and O'Sullivan of an occasion at Serra's church (i.e., Carmel Mission), in which the children and adult cantors gave an ethereal performance of the "Alabanzas de Maria," alternating phrases antiphonally, the boy-sopranos calling out and the men-baritones answering. The vocal contrast must have been further enhanced by the physical separation of the two groups in the sanctuary. Saunders and O'Sullivan relate the story as follows:

The Father explained that there was to be a special service in the Serra church that evening, in which the children were to sing .... The church was dimly lit except where the candles lit up the beautiful altar. The service was short, made up in part of the singing of Alabanzas de María, or Praises of Mary, which consisted, as I remember, entirely of unaccompanied chants by the children, who sang alternately with chanters located in the body of the church, one group singing after another, the lovely music all the more appealing in the children's endearing treble. It was the devotion of el Mes de Mayo - the Month of May.

\section{Conclusion}

We see a microcosm of mission music making at the feast of Pentecost on 3 June 1770, when Serra laid the groundwork for what was to become the Carmel Mission, his home church. This occasion was full of pageantry, procession, song, gunfire, plainchant, strummed homophony, and perhaps even some rudimentary polyphony. The musical performances of Veni Creator Spiritus, the Salve, the Te Deum, the alabado, and the alba provided an experience that was rewarding for the participants and probably fascinating for the indigenous Californians in the region, whom the friars were trying to attract. One could hardly pick pieces more beautiful or appealing than these. Their compositional attributesstraightforward yet varied, simple yet inviting - are apt metaphors for life in California as it evolved during the early nineteenth century. And if we look back at these attributes that were so heartily embraced by our ancestors, we might find that they still serve as worthy models for us, even now.

Notes

Craig Russell is a professor of music at California Polytechnic State University. He frequently lectures at musicological conferences and conventions in North America, 
Mexico, and Spain and has published over forty articles on eighteenth-century Hispanic studies, Mexican Cathedral music, the California Missions, baroque guitar music, and American popular culture. His two-volume study, Santiago de Murcia's "Codice Saldivar No.4": A Treasury of Secular Guitar Music From Baroque Mexico, was published in 1995 by the University of Illinois Press. He has received major grants from the National Endowment for the Humanities, the Fulbright Commission, Spain's Ministry of Culture, the Program for Cultural Cooperation, the California Council for the Humanities, and the Edmund Cabot Memorial Fund. Active as a composer, his works include two musical comedies (Zapatera! and It's a Man's World-Or Is It?), two symphonies, solo concertos for various instruments including guitar, horn, piano, and bass, numerous chamber pieces and several solo guitar works. Email: crussell@calpoly.edu

1. This article is a modified version of chapter 3, "Serra and the Introduction of Sacred Song: Veni Creator Spiritus, Salve, Te Deum, and Alabado," of my book, From Serra to Sancho: Music and Pageantry in the California Missions (New York: Oxford University Press, 2009). Much has been written on Serra, and so a biographical summary here seems unnecessary. For those desiring more information on Serra's life, accomplishments, and personality, I refer the interested reader to two immensely rewarding books: Francisco Palóu, Francisco Palóu's Life and Apostolic Labors of the Venerable Father Junipero Serra, Founder of the Franciscan Missions of California, trans. C. Scott Williams introduction and notes by George Wharton James (Pasadena, CA: George Wharton James, 1913); and Maynard J. Geiger, O.F.M., The Life and Times of Fray Junípero Serra, O.F.M., or The Man Who Never Turned Back (1713-1784), 2 vols. (Washington, D.C.: Academy of American Franciscan History, 1959).

2. Francis J. Weber has authored several important studies that help the scholar or interested reader to find primary-source material regarding almost any aspect of past life in California, including some of the music traditions covered in this article. Weber provides a useful checklist of travelers who wrote firsthand accounts of their experiences in California, and many of those recollections describe musical events. See Weber, "The California Missions and Their Visitors," The Americas 24, no. 4 (1968): 319-36. Also, for those wishing to navigate through the available primary-source material in California, Weber's research guide is particularly useful; consult "Archival Sources for the History of Religion in California. Part I: Catholic Sources," Southern California Quarterly 72, no. 2 (1990): 157-72.

3. "Para dar la comunión al capitán y soldados que desde Santa María havía ido a confessar para cumplimiento del annuo precepto, y prevenirse para la expedición; y se dize haver sido aquella la $1^{\mathrm{a}}$ misa, por que ahunque estuvo allí en su viage el Padre Jesuíta Link como consta de su diario, dizen los soldados que lo acompañavan, que no celebró allí. En aquel xacal pues se dispuso el altar, se pusieron los soldados con sus cueras y adargas sobre las armas y con todos los asseos de la santa pobresa, celebré mi misa en aquel día tan grande con el consuelo de ser la $1^{\text {a }}$ de las que ya se havían de continuar, con la permanencia de aquella nueva Misión de San Fernando, que desde aquel día comenzava, la que mientras duró solemnizaron las muy repetidas descargas de las armas de los soldados, supliendo por esta vez los humos de la pólvora, por los de incienso que no podíamos ofrecer, por que no lo teníamos. Y como no havía más cera que la que ardía que era un cabito de vela que me hallé y el cerillo del padre, fué por aquel día la misa única y la oyó el padre con los demás en cumplimiento del precepto. Después cantamos Veni Creator Spiritus de $3^{\text {a }}$. El concurso lo hizimos nosotros, los soldados y los indios neófitos, que nos acompañavan, sin que asomase gentil alguno, quizás 
asustados con tantos truenos." Junípero Serra, Writings of Junípero Serra, ed. Antonine Tibesar, O.F.M., 4 vols (Washington, D.C.: Academy of Franciscan History, 1955), 1:60-61. Note that I have made two small corrections to Tibesar's translation of this passage. He incorrectly translates the term soldados as the singular "soldier" as opposed to the plural "soldiers" in the passage, "there was only one mass, at which the Father assisted together with the soldier[s]," and he fails to address the numeral " 3 " after Veni Creator. I strongly suspect the numeral was an "8" as opposed to a "3," since this sequence is in mode 8 , and it was customary to identify a piece by its modal properties. This same event is covered in Geiger's Life and Times of Fray Junípero Serra, 1:218. Other sources thoroughly treating this founding include Rose Marie Beebe and Robert M. Senkewicz, Lands of Promise and Despair: Chronicles of Early California, 1535-1846 (Santa Clara, CA: Santa Clara University; Berkeley: Heydey Books, 2001), 137-41; and Alexander Forbes, California: A History of Upper and Lower California from the First Discovery to the Present Time (1839), introduction by Herbert Ingram Priestley (San Francisco: John Henry Nash, 1937; repr. New York: Kraus Reprint, 1972), 62-63.

4. "El dia siguiente, 14 de Mayo (como queda dicho) y primero de Pascua del Espíritu Santo, se dió principio á la fundación.... Y habiendo cantado la Misa primera, hizo una fervorosa Plática de la venida del Espíritu Sancto, y establecimiento de la Mision. Concluido el Santo Sacrificio (que se celebró sin mas luces que las de un cerillo, y otro pequeño cabo de vela, por no haber llegado las cargas en que venia la cera) cantó el Veni Creator Spiritus, supliendo la falta de Organo, y demás instrumentos músicos, los continuos tiros de la Tropa, que disparó durante la función; y el humo de la pólvora, al del incienso que no tenian." Francisco Palóu, Relación histórica de la vida y apostólicas tareas del venerable Padre Fray Junípero Serra, y las misiones que fundó en la California Septentrional, y nuevos establecimientos de Monterey (Mexico City: Don Felipe de Zúñiga y Ontiveros, 1787); facsimile ed. March of America Facsimile Series 49 (Ann Arbor, MI: University Microfilms, 1966), 70.

5. In the Roman rite, Veni Creator Spiritus is associated with the dedication of a church, which explains its importance in the founding days of the various missions.

6. For a thorough discussion of the 1780 code of regulations developed by the Franciscans at the Colegio Apostólico de San Fernando, consult chapter 22 of Geiger's Life and Times of Junípero Serra, esp. 166-67. Significantly, Veni Creator Spiritus had a long tradition of being used at the inauguration of new sacred worship spaces. For instance, the ceremony to open the new cathedral in Lima on 19 October 1625 began with the pealing of the bells, followed by a rendition of Veni Creator Spiritus. "Comenzó la orquesta a entonar el himno Veni Creator y después las letanías," and then they celebrated "con mucha mússica [sic] de canto de órgano." See Andrés Sas Orchassal, La música en la Catedral de Lima durante el Virreinato, vol. 1: Primera Parte: Historia General, Colección de Documentos para la Historia de la Música en el Perú (Lima: Universidad Nacional Mayor de San Marcos and Casa de Cultura del Perú, 1971), 28-29.

7. Choirbook C-C-68:2 in the Bancroft Library, 112bis. The handwriting and the gluing together of two sheets into single folios (as seen in this manuscript) match perfectly the handwriting and construction of Santa Clara Ms. 3; both of these choirbooks were prepared by Florencio Ibáñez.

8. The Gregorian model can be found in the Liber Usualis, 885-86. 
9. Canto figurado consisted of a single homophonic melodic line in a steady meter with a supporting harmonic accompaniment. Canto de órgano, on the other hand, consisted of a group of polyphonic lines, most often in four-voice texture. Its lines were mensural (as were those in canto figurado), but there was greater variety in meters and note values in canto de órgano than in canto figurado. For more information on these styles, consult chapter 1, "Musical Style and Performance in Mission Life," in my book From Serra to Sancho.

10. It is worth noting here that the California sources alter significantly the renditions of sequences that historically had been performed as paired phrases $\left(a-a^{\prime}, b-b^{\prime}, c-c^{\prime}\right.$, $\mathrm{d}-\mathrm{d}^{\prime}$, etc. $)$ and instead couch the very same words but in strophic settings $\left(a-a^{\prime}-a^{\prime \prime}-\right.$ $a^{\prime \prime \prime}-a^{\prime \prime \prime \prime}$, etc.). Some sources offer a variant of the strophic form where a contrasting pair of phrases come back repeatedly in alternatim style so that all of the odd-numbered phrases are set to a musical phrase $a$ and the even-numbered phrases are set to a contrasting musical phrase $b$, resulting in the pattern $a-b, a^{\prime}-b^{\prime}, a^{\prime \prime}-b^{\prime \prime}, a^{\prime \prime \prime}-b^{\prime \prime \prime}, a^{\prime \prime \prime \prime}-b^{\prime \prime \prime \prime}$, etc. Therefore, in the California mission tradition, there is a marked similarity between "hymns" and "sequences," for the two genres can share structural features. In both cases, they usually alternate phrases between two opposing and contrasting phrases. For text settings in alternatim style, consult Veni Sancte Spiritus (Santa Clara Ms. 4, 15; Santa Clara Ms. 3, 34; Bancroft choirbook C-C-82:2, 57; Bancroft choirbook C-C-59, 27; WPA fol. 54); Dies irae (Bancroft choirbook C-C-59, 67); Lauda Sion Salvatorem (Bancroft choirbook C-C-82:2, 67; San Juan Bautista Ms. 1, 29 (plate 48 in WPA item 45); Santa Clara Ms. 3, 48 and B-Bv; Serra choirbook M.0612, fol. 12v); Victimae paschali laudes (Santa Clara Ms. 4, 10; Bancroft choirbook C-C-59, 19); and Vexilla Regis (Bancroft choirbook C-C-59, 17).

For the previous citations, those sources with the prefix "Santa Clara" are found in the Orradre Library of Santa Clara University. The Bancroft Library at the University of California at Berkeley owns the choirbooks referenced with the prefix "Bancroft." The "Serra choirbook M.0612" is found at the Green Research Library at Stanford University. The prefix "WPA" refers to the invaluable collection of photographs owned by the Department of Music at the University of California at Berkeley. These photos are catalogued as "WPA Folk Music Project. Items 45-87, box 2 of 12. California Folk Music Project Records, ARCHIVES WPA CAL 1." The photographs were made in 1937 as part of the Work Progress Administration (WPA) that later changed its name to the Works Projects Administration. For a detailed account of this collection's history, including its rediscovery by John Koegel and its scholarly examination by Bill Summers, consult the file "WPA Folders" in appendix A of my recent book, From Serra to Sancho.

11. For an excellent retelling of the events surrounding the early expeditions to California and the founding of the Mission San Diego, consult David J. Weber, The Spanish Frontier in North America (New Haven, CT: Yale University Press, 1992), $243-44$.

12. "Llegó el día, se formó capilla, y altar, junto a la misma barranquita y encino, todo immediato a la playa donde se dize haverse celebrado en los principios de la centuria passada. Veníamos a un mismo tiempo al parage por distinctos rumbos los de mar, y los [de] tierra, nosotros cantando en la lancha las divinas alabanzas, y los señores de tierra en sus corrazones.

Llegados y recibidos con repiques de las campanas colgadas del enzino, dispuesto todo lo necesario haviéndome revestido de alva y estola, incado con todos ante el altar 
entoné el hymno Veni Creator Spiritus, el qual concluído, e invocada por este medio la asistencia del Divino Espíritu para quanto ívamos a executar, bendixe sal y agua, y nos encaminamos todos a una cruz grande prevenida, y tendida en el suelo, la que entre todos levantamos, canté su bendición, la fixamos, y adoramos todos con ternura de nuestros corazones, rocié con agua bendita aquellos campos, y levantado assí el estandarte del Rey del Cielo, se erigieron los de nuestro cathólico monarca, celebrándose uno y otro con altas vozes de Viva la Fe Viva el Rey, que acompañavan, repiques de campanas, y tiros de fusileria, y cañones del barco.

Luego hizimos al pie de la cruz el entierro de un diffunto marinero calafate el único que ha muerto en este barco en esta $2^{\mathrm{a}}$ expedición.

Y concluydo comensé la missa cantada, que llevó después del evangelio su sermón y toda fué muy acompañada de cañonasos. Concluída y despuesta la casulla cantamos todos la salve en romance ante la bellísima imagen de Nuestra Señora que ocupava el altar y la dió el Ilustrísimo Señor Visitador General para esta función cum onere de debolvérsela después, como lo haré assí que marche el barco.

Y para conclusión, puesto en pie, entoné el Te Deum Laudamus, que pausada, y solemnemente seguimos hasta su fin que se dió con los versos y oraciones de la Santíssima Trinidad, de Nuestra Señora, del Santíssimo San Joseph, patrón de la expedición, San Carlos, que lo es de este puerto, presidio y misión y la de acción de gracias."

The core of this translation is by Antonine Tibesar, from his Writings of Junipero Serra, 1:169. However, in a few instances Tibesar alters Serra's original statements, painting a slightly different picture of the event. In these specific locations, I have made the following modifications and alterations to Tibesar's core:

In Serra's letter, he observes, "Veníamos a un mismo tiempo al parage por distinctos rumbos los de mar, y los [de] tierra." Serra does not limit himself to two directions, as Tibesar translates, and the term rumbos does not limit the procession to only one path from the sea and one path from the land, but instead implies that there are several directions simultaneously, i.e., those from the sea and those from the land.

Tibesar's translation depicts an almost linear event, whereas Serra's text allows for clusters of events to have been occurring from multiple angles. I therefore have changed Tibesar's text from "Two processions from different directions converged at the same time on the spot, one from the sea, and one from the land expedition" to "We came to the same spot at the same time from different directions, those from the sea and those from the land."

In the ensuing paragraph, Serra continues "Y levantado assí el estandarte del Rey del Cielo, se erigieron los de nuestro cathólico monarca, celebrándose uno y otro con altas vozes de Viva la Fe Viva el Rey." The passage in question states that there is one flag for the King of Heaven, but several for the King of Spain. This latter reference "los de nuestro cathólico monarca" is unmistakably plural. I therefore have altered Tibesar's translation from "And thus, after raising aloft the standard of the King of Heaven, we unfurled the flag of our Catholic Monarch likewise" to "And thus, after raising aloft the standard of the King of Heaven, we unfurled the flags of our Catholic Monarch likewise." The potential for a more impressive and colorful display is allowed by Serra's original description, for the unfurling of multiple flags (not just two) to the accompaniment of cannon shots and the volleys from their rifles could have been prolonged and more spectacular in effect.

I made several other changes to Tibesar's translation to clarify Serra's musical observations. Near the end of the quoted passage Serra observes, "Concluída y 
despuesta la casulla cantamos todos la salve en romance ante la bellísima imagen de Nuestra Señora." Tibesar translates the phrase as "all together we sang in Spanish the Salve Regina, in harmony, in front of the wonderful painting of Our Lady." Nowhere is there a mention of "harmony," and so I have removed this qualifier. Also, Serra does not mention the "Salve Regina" but instead only the "Salve." There are other possibilities. I therefore have translated Serra's original designation of "la salve en romance" as "the Salve in the Spanish language" without any potentially misleading additions to either harmony or the Marian antiphon Salve Regina.

Tibesar also departs slightly from Serra's original when translating the passage "entoné el Te Deum Laudamus ... con los versos y oraciones de la Santíssima Trinidad." Tibesar translates the passage as "I intoned the Te Deum Laudamus; ... with the responses [sic] and prayers to the Most Holy Trinity." Tibesar's decision to translate versos as "responses" is a misleading alteration. The latter term has its own variable meanings, indicating structural aspects and also performance practice, whereas versos merely implies the verses of the text. I therefore have replaced Tibesar's "responses" with "verses" in the appropriate location.

Before abandoning the discussion of this passage, it should be noted that Maynard Geiger provides another useful translation in his study, The Life and Times of Junipero Serra, 1:247-48. It is meritorious and fluid, and in some instances is more accurate that Tibesar. For instance, Geiger captures the ambiguity regarding the varied directions of the initial approaches from land and sea instead of lining them up in singular directions as Tibesar does. Also, Geiger captures the sense of Serra's text with respect to the flags of the monarch, as opposed to a single flag for the monarch. Even Geiger's translation, however, has a few limitations that should also be addressed. He completely expunges the passage concerning the burial of the soldier, with no indication that there has been material removed from the excerpt. He similarly alters the reference to the "Salve" to "Salve Regina" and in so doing makes a clarification based on assumptions rather than evidence. He translates "imagen de la Virgen" as a "statue" of the Virgin as opposed to a "painting," which is Tibesar's interpretation of the word imagen. The Spanish term imagen can designate either; until further evidence is unearthed, it is wise to remain open to the possibility that Serra used either a painting or a sculpture at this mission's founding. Serra's text itself remains frustratingly ambiguous on this matter. Geiger states that they intone the Te Deum, "observing the pauses." In actuality, Serra's use of the adjective pausada refers to the measured and deliberate way that the work was sung, not the actual inclusion of "pauses." Thus, when Serra explains "entoné el Te Deum Laudamus, que pausada, y solemnemente seguimos hasta su fin," he is stating, "I intoned the Te Deum Laudamus that we sang and continued until its end in a solemn and deliberate manner."

13. "On the following day, about twenty priests, with their president, were in attendance at the church to chant a Te Deum, assisted by thirty Indian musicians [i.e., instrumentalists] collected from the different musicians, together with an equal number of singers. Governor Sola, escorted by the late governor and all the officers of the staff and garrison, walked to the temple, and amidst the salutes of the artillery of the fort, and of the cavalry here stationed, partook in the solemn services, which ended with an eloquent and appropriate sermon by Fray Vicente." Hubert Howe Bancroft, California Pastoral, 1769-1848, vol. 34 of The Works of Hubert Howe Bancroft (San Francisco: San Francisco History Company, 1888), 421-22. Larry Warkentin provides an abbreviated summary of this same event (placing the year in 1815, whereas Bancroft places it in 1816) in "The Rise and Fall of Indian Music in the California Missions," Latin 
American Music Review 2, no. 1 (1981): 50. Warkentin provides the added information that the musicians were led by the neophyte José el Cantor, "the favorite pupil of Florencio Ibáñez."

14. Ratkay's account reads: "The sailors and soldiers were aroused from their sleep, and the mate set the sails. Then followed mass, or at least a morning prayer. At nine o'clock a bell announced breakfast.... After breakfast chocolate was served to those who desired it, and then the passengers did whatever they pleased.... At four in the afternoon dinner was eaten in the same manner as breakfast. After sunset the signal was given for evening prayer, which included the singing of the Laurentian Litany and the Salve Regina." Baegert's description of Saint Peter's and Saint Paul's feast day reads, "All people took communion, by which devotion the captain and other gentlemen gave a good example for the common man. In the evening, some cannons were fired while singing the Te Deum." Quotation from Kristin Dutcher Mann, "The Power of Song in the Missions of Northern New Spain" (PhD diss., Northern Arizona University, 2002), 50-51.

15. For a discussion of these four Marian antiphons, consult John Harper, The Forms and Orders of Western Liturgy from the Tenth to the Eighteenth Century: A Historical Introduction and Guide for Students and Musicians (Oxford: Clarendon Press, 1991), 132-33, 274-75; Richard Hoppin, Medieval Music (New York: Norton, 1978), 104-05; and the Liber Usualis, 273-76.

16. Since Sancho does not always sign his music, a few words pertaining to his handwriting are in order, since several scribal idiosyncrasies can help identify unlabeled sheets as being his work. The sheet with Salve Regina at the San Fernando Mission is catalogued by William Summers as manuscript S-5; see Summers, "Opera seria in Spanish California: An Introduction to a Newly-Identified Manuscript Source," in Music in Performance and Society: Essays in Honor of Roland Jackson, ed. Malcolm Cole and John Koegel (Warren, MI: Harmonie Park Press, 1997), 276. At the end of the Salve Regina, Sancho draws his distinctive "double bar" that he often uses to mark the conclusion of a work, where rows of small semicircles protrude to the right of the double bar, with the first row having five of these circles, and with each progressive row having one fewer semicircle than the previous one. The drawing resembles a pyramid of stacked oranges that have been glued together and then turned sideways so that the "peak" of the pyramid points to the right. Other Sancho manuscripts with this pyramid-like double bar at the conclusion of the work include the following works in the WPA folders of the University of California at Berkeley: WPA fol. 58, "Admirabile nomen Jessu”; WPA fol. 61, "Lamentatio a duo"; WPA fol. 64, "Misa de quinto tono"; WPA fol. 66, "Credo Italiano a duo"; WPA fol. 69, "Missa de los Angeles"; and WPA fol. 72, "Missa de Requiem." There are other sources at the San Fernando Mission-in addition to the aforementioned Salve Regina in Sancho's hand-that contain his recognizable handwriting. Manuscript S-1 -5 has jotted down on its sheets a mass that begins with a "Kyrie Clasichs" and the "Gloria simple": Sancho draws his distinctive pyramid-like double bar to conclude this composition. It should also be noted that Pedro Cabot uses this same pyramid-like drawing at the conclusion of "O Christe mundi Salvador" in WPA fol. 60.

17. Manuscript S-5 at the San Fernando Mission has been folded to make a small booklet consisting of two smaller folios, a total of four pages, and it contains the music for Compline, as described and clearly mapped out by Jerome Roche, "Musica diversa di Compietà: Compline and its Music in Seventeenth-Century Italy," Proceedings of the 
Royal Musical Association 109 (1982-83): 60-79, esp. 62. See also Harper, The Forms and Orders of Western Liturgy, 82-83. The Salve Regina was widely known in the Gregorian tradition (see Liber Usualis, 276). For further annotations concerning the construction of manuscript S-5 at the San Fernando Mission, consult appendix A available online in conjunction with my From Serra to Sancho, which also provides information regarding the similarities (or lack thereof) of these chants to those in the Gregorian tradition. Observe that manuscript S-5 at San Fernando has a strong connection to Santa Clara Ms. 3 (fols. 55v-56v). For this Compline service, both manuscripts share melodies not matching Gregorian models. One of the main points of interest here concerns the role of Pedro Cabot in his collaboration as a scribe with two of the central figures in California mission music; we find Cabot interpolating material into the Compline service for both the San Fernando manuscript S-5 (where Juan Sancho is the scribe) and Santa Clara Ms. 3 (where Ibáñez is the principal scribe).

18. The definitive authority on the Salve and its performance in the New World, Robert J. Snow, provides a summary of its history in the Franciscan monasteries and publications, supplying the tunes as they appear across the Hispanic world, and none of them match the tune that Sancho has written down. See Snow, A New World Collection of Polyphony for Holy Week and the Salve Service "Guatemala City, Cathedral Archive, Music MS 4" (Chicago, IL: University of Chicago Press, 1996), esp. 68-74.

19. Durán writes out the "Salve Virgen pura" in Bancroft choirbook C-C-59, 73, Santa Barbara Doc. 1, 171, and Santa Clara Ms. 4, 67 and 68. (See photo B-114 in appendix B online of From Serra to Sancho for a facsimile of page 68.) Other California manuscripts contain related material, including Santa Barbara Doc. 2, 87, and folder C at Santa Barbara, where Maynard Geiger twice wrote out the stanzas for this song. All sources with the prefix "Santa Barbara" are found in the Santa Barbara Mission Archive-Library.

20. Although the Castilian word salvar means "to save" or "to rescue," in this context it actually means "hail," derived from the phrase "Dios te salve, María, llena de gracia," meaning "Hail, Mary, full of grace." See Diccionario moderno español-inglés,

English-Spanish Larousse, ed. Ramón García-Pelayo y Gross and Micheline Durand (Paris: Ediciones Larousse, 1979), 374. This text was also known as the Alabanza, according to Charles Francis Saunders and Father St. John O'Sullivan. They base their analysis and discussion on the recollections of Doña María, who grew up in the mission period. She recalls that this hymn in honor of the Blessed Virgin was sung on Sundays, as a substitute for the singing of the alba that began the other days of the week. See Saunders and O'Sullivan, Capistrano Nights: Tales of a California Mission Town, illustrated by Charles Percy Austin (New York: Robert McBride, 1930), 155-57.

21. A color facsimile of this "Dios te salve Reyna madre" can be found in Lorenzo Calzavarini's Breve guía histórica, artística y cultural del Convento San Francisco de Tarija (en el IV Centenario de su fundación, 1606-2006) (Santa Cruz, Bolivia: Editorial Centro Eclesial de Documentación, 2006), 93.

22. For information concerning the Sisters of Charity School graduation, consult Robert Stevenson, "Music in Southern California: A Tale of Two Cities,"

Inter-American Music Review 10, no. 1 (1988): esp. 58-59. He provides a facsimile of the printed tune of "Dios te salve Maria" and four stanzas on page 59 of the article. 
23. The Bancroft Library, Ms. C-C-73/108c. "Copia del manuscripto Ramón Yerba [sic]. Cantos de la Misión." The last name should read "Yorba" and is in fact spelled correctly throughout the bulk of the document. Hereafter, I abbreviate this source as the "Yorba manuscript."

24. The pedigree of the Yorba manuscript, Ms. C-C-73/108c, is worth retelling, as recorded in the preface to his volume $(1-7)$. I provide the entire text as item C-5 in appendix C online of From Serra to Sancho under the section for the Bancroft Library.

25. Preface to the Yorba manuscript, Ms. C-C-73/108c in the Bancroft Library.

26. Santa Clara Ms. 3, fols. 56v-57.

27. For a discussion of the Matins service in the context of Mexican society in the Baroque and Classical eras, consult my entry "Eighteenth Century" for the Encyclopedia of Mexico: History, Society and Culture, ed. Michael Werner (Chicago, IL: Fitzroy Dearborn, 1998). I address the importance of Matins in Mexico as the central theme in "The Apparition of the Virgin of Guadalupe and Her 'Reappearance' in the Choral Masterpieces of Eighteenth-Century Mexico," paper presented at the annual meeting of the American Musicological Society, Phoenix, 30 October-2 November 1997, and at the annual convention of the College Music Society, Cleveland, 13-16 November 1997. Further relevant information can be found in my article "Hidden Structures and Sonorous Symmetries: Ignacio de Jerusalem's Concerted Masses in Eighteenth-Century Mexico," in Res musicae: Essays in Honor of James Pruett, ed. Paul R. Laird and Craig H. Russell (New York: Harmonie Park Press, 2001), 135-59. For treatment of the Te Deum, consult Harper, The Forms and Orders of Western Liturgy, 83-84, 90, 93, 270 71; and the Liber Usualis, 1832-37.

28. Herbert Eugene Bolton, Anza's California Expeditions: An Outpost of Empire, vol. 1 (Berkeley: University of California Press, 1930), 367-68.

29. "Salimos de dicho Presidio de Monterey el $S^{r}$ Comandante, yo y otros pocos â las quatro de la tarde, y â las cinco llegamos â la Mission de San Carlos del Carmelo senalada en el mapa con la letra G. haviendo caminado una legua larga con el rumbo al sudoeste quarta al sur. Aqui nos recibimos los Padres que eran siete cantando el tedeum, con festivos repiques y singular alegria." Pedro Font, The Anza Expedition of 1775-1776: Diary of Pedro Font, ed. Frederick J. Teggart, Publications of the Academy of Pacific Coast History 3/1 (Berkeley: University of California Press, 1913), 60-61.

30. See note 12 for the entire quotation.

31. Santa Clara Ms. 3, fols. 83-84v.

32. Liber Usuali: "Solemn Tone" formula on 1832-34; "Simple Tone" begins on pages $1834-36$.

33. See the instructions in the Liber Usualis, 1833 and 1836.

34. There are several concordant versions of this setting of the Te Deum in fauxbourdon technique in which the same formulaic harmonic pattern is used to accommodate the rhythmic and textual variants of the odd-numbered lines of this text. This model was clearly well known, given its common recurrence across California. For concordant versions of the same musical and textual setting, consult Bancroft choirbook C-C-59, 119; Bancroft choirbook C-C-68:1, fols. 30v-31; Santa Clara Ms. 4, 122; Santa Barbara Doc. 2, 84-85; and Santa Barbara Doc. 10, fol. 1. 
35. See photo 5-9 in chapter 5 of From Serra to Sancho for a facsimile of the title page of WPA fol. 77, "Te Deum a 4 voces alternando con las del coro."

36. The monophonic formula in Santa Clara Ms. 3 is in transposed mode 2 with an emphasis on A (sounding a bit like A minor to modern ears). The jumps between modes 6 and 2 (or the keys F major to A minor) are not entirely satisfactory or fluid. Similarly, Durán clarifies that the interpolated passages need to be either in C major or A minor, and the sixth mode (or "F major") of WPA fol. 77 does fit the bill.

37. The history of this recording and notated transcription of it is found in Charles Francis Saunders and J. Smeaton Chase, The California Padres and Their Missions (Boston, MA: Houghton Mifflin, 1915), 372-74.

38. Owen da Silva, O.F.M., Mission Music of California: A Collection of Old California Mission Hymns and Masses (Los Angeles, CA: Warren F. Lewis, 1941), 120.

39. For the five-measure fragment of the alabado in the Sancho materials, consult the WPA collection at the University of California at Berkeley, fol. 68: photograph W-2, staff 6; and photograph W-4, staff 13 (for this image, the sheet must be rotated $180^{\circ}$ because the passage is written upside down). For extra stanzas of lyrics that can be supplied to these tunes, consult folders A, C, F, and G of lyrics copied out by Father Maynard Geiger, O.F.N., that are stored in the "Music" filing cabinet at the Santa Barbara Mission Archive-Library.

40. For the notated version of the alabado, consult da Silva, Mission Music of California, 112-13; Saunders and Chase, The California Padres, 373-74; and Stevenson, "Music in Southern California," 55.

41. The reference to the alabado is found on an index that is now an end paper for another source, Manuscript 2 at the San Juan Bautista Mission. We can ascertain what works had been included (even though the book is not extant) by examining the index for that work. The relevant page can be found as plate 136 in the photos of the San Juan Bautista sources in the bound volume, item 45 in the WPA collection at the Department of Music of the University of California at Berkeley.

42. Leonardo Waisman, "VViva María! La música para la Virgen en las misiones de Chiquitos," Latin American Music Review 13, no. 2 (1992): 214.

43. John Koegel, "Spanish and French Mission Music in Colonial North America," Journal of the Royal Music Association 126 (2001): 25-26.

44. Koegel, "Spanish and French Mission Music," 33.

45. McGill goes on to develop her points further, including the practice mission music by the Tigua Indians near El Paso. See Anna Blanche McGill, "Old Mission Music," Musical Quarterly 24, no. 2 (1938): 188-89.

46. See Kristin Dutcher Mann, "The Power of Song in the Missions of Northern New Spain” (PhD diss., Northern Arizona University, 2002), 175-83, esp. 180.

47. See John Donald Robb, Hispanic Folk Music of New Mexico and the Southwest: A Self-Portrait of a People (Norman: University of Oklahoma Press, 1980), 612-43; and Vicente T. Mendoza, Panorama de la Tradicional de México, Instituto de Investigaciones Estéticas, Estudios y Fuentes de Arte en México 7 (Mexico City: Universidad Nacional Autónoma de México, 1984), esp. 39-40. After the main body of the text he provides musical examples (on unnumbered pages) of the alabado; see nos. 30-35. In addition, 
plate 20 at the back of the book is a facsimile of the single sheet "Alabado dispuesto por el R. P. Fr. Antonio Margil de Jesús" published in a bilingual edition by Federico Gómez de Orozco, Mexico City, in the early 1700s. The lyrics presented here of Margil's alabado make no appearance in California manuscripts. Mendoza provides another exhaustive study of the alabado providing specific tunes and texts. See Vicente T. Mendoza and Virginia R. R. de Mendoza, Estudio y clasificación de la música tradicional hispánica de Nuevo México, Instituto de Investigaciones Estéticas, Estudios de Folklore 5 (Mexico City: Universidad Autónoma de México, 1986), 30-51. The flourishing of the alabado in New Mexico through the centuries is the subject of Thomas J. Steele's The Alabados of New Mexico, ed. and trans. Thomas J. Steele (Albuquerque: University of New Mexico Press, 2005). He provides many texts in Spanish and English translation, but no melodies are included.

48. One of the most comprehensive discussions of mission life at the San José de Comundú Mission in Baja California is found in Harry Crosby, Mission and Colony on the Peninsular Frontier, 1697-1768 (Albuquerque: University of New Mexico Press, 1994), esp. 237-39. John Koegel also delves into this material in his indispensable article, "Spanish and French Mission Music esp. 29. A third scholar, Francis J. Weber, provides a thorough explanation and insightful observations concerning mission life in "Jesuit Missions in Baja California," The Americas 23, no. 4 (1967): esp. 414-15.

49. Crosby, Mission and Colony, 238.

50. Crosby, Mission and Colony, 238-39. A comparison of this account of mission life in the Jesuit missions of Baja California with that of Miguel de Barco and with yet another by Pablo Tac during his youthful days in the Franciscan missions of Alta California in the 1820s reveals a nearly identical regimen. For an exploration of Tac's life story and fascinating recollections from Mission San Luis Rey, consult Beebe and Senkewicz, Lands of Promise and Despair, 329-40, esp. 335-36.

51. Beebe and Senkewicz, Lands of Promise and Despair, 95.

52. Crosby, Mission and Colony, 239.

53. Stevenson, "Music in Southern California," 40 and 55. On page 55, Stevenson provides a facsimile of a print containing the music and lyrics; it differs completely from the version notated in da Silva's Mission Music of California, 112-13.

54. Rev. Francis J. Weber, Readings in California Catholic History (Los Angeles, CA: Westernlore Press, 1967), 20-21.

55. Saunders and Chase, The California Padres, 369.

56. The lengthy account of Vicente de Santa María is well worth reading in its entirety and is chock-full of fascinating details on a wide variety of subjects. It is reproduced in Beebe and Senkewicz, Lands of Promise and Despair, 177-85.

57. Beebe and Senkewicz, Lands of Promise and Despair, 181.

58. Beebe and Senkewicz, Lands of Promise and Despair, 181.

59. Beebe and Senkewicz, Lands of Promise and Despair, 184.

60. Santa Barbara Doc. 1, 178-79; San Juan Bautista Ms. 2, 44 (plate 196 in the photos of this source as part of item 45 in the WPA collection). The text runs, "Dios te salve Maria, llena eres de gracia, el Señor es contigo, bendita tu eres entre todas las 
mugeres. Y bendito es el fruto de tu vientre, Jesus. Gloria Patri et Filio et Spiritui Santo."

61. "Todos los Domingos de Quaresma no se contentaba con la Pláctica Doctrinal de la Misa mayor, sino que á la tarde, después de rezada la Corona de María Santísima, y cantado el Alabado, les predicaba un Sermon Moral." Palóu, Relación histórica de...

Serra, 30. The "Corona de María Santísima" to which Palóu refers is the prayer written around 1628 by San José de Calasanz. It contains twelve acclamations of "Hail Mary," reflecting the twelve graces bestowed by the Trinity (four by the Father, four by the Son, and four by the Holy Spirit). The imagery is based upon the passage in Revelation by John the Evangelist: "And there appeared a great wonder in heaven; a woman clothed with the sun, and the moon under her feet, and upon her head a crown of twelve stars" (Revelations 12:1). For information on the Crown of the Immaculate Conception of the Blessed Virgin, consult "Devoción a María, Corona de las Doce Estrellas [i.e., the Crown of the Immaculate Conception]," by San José de Calasanz (ca. 1628), Devocionario Católico, http://www.devocionario.com/maria/corona_estrellas.html (accessed 4 August 2004). There are many iconographic depictions of Mary with her crown of twelve stars, the Stellarium, associated with the Conception. See Suzanne L. Stratton, The Immaculate Conception in Spanish Art (Cambridge: Cambridge University Press, 1994). With respect to this imagery's relevance as seen in Mexican music of the time, see Drew Edward Davies, "The Italianized Frontier: Music at Durango Cathedral, Español Culture, and the Aesthetics of Devotion in Eighteenth-Century New Spain" (PhD diss., University of Chicago, 2006), esp. chap. 5 (UMI Microfilm No. 3206320).

62. “Con igual cuidado se dedicó á introducirlos en la devocion de Maria Srá. Nuestra, y con particularidad á su Purísima Concepcion inmaculada, previendose á celebrarla con la Novena, á que asistia todo el Pueblo; y en el dia de esta gran festividad se cantaba la Misa, y predicaba el Sermon, y despues se entonaban los Gozos de la Purísima Concepcion. Todos los Domingos por la tarde se rezaba la Corona á la Madre de Misericordia, concluyendola con el Alabado ó con los Gozos que se cantaban. Y para mas aficonarlos el V. Padre pidió de México una Imagen de bulto de la dulcísima Señora, que puesta en sus andas, la sacaban en Procesion por el Pueblo todos los Sabados de noche, alumbrando con faroles, y cantando la Corona." Palóu, Relación histórica de... Serra, 32.

63. The association of Saturday mass with veneration of the Virgin Mary is seen across the Americas. For instance, this relationship as practiced in the Chiquitos missions of Paraguay is explored in Waisman, "iViva María!," 214.

64. Fr. Zephyrin Engelhardt, O.F.M., Mission San Antonio de Padua: The Mission in the Sierras, Missions and Missionaries in California, New Series: Local History (Ramon, CA: Ballena Press, 1972), 35.

65. Alfred Robinson provides a snapshot of the evening activities at Mission San Luis Rey, including the supplication to the Virgin. Consult Robinson, Life in California: A Historical Account of the Origin, Customs, and Traditions of the Indians of Alta-California, foreword by Joseph A. Sullivan (Oakland, CA: Biobooks, 1947), esp. 17. José del Carmen Lugo's memoirs of his life on a rancho near Mission San Antonio include his recollections of evening prayers and the reciting of the rosary. See "1840s: Life on a California Rancho [by] José del Carmen Lujo," in Beebe and Senkewicz, Lands of Promise and Despair, 434-42, esp. 434. 
66. From Antonio Colonel's Tales of Califormia from the 1840s, quoted in Beebe and Senkewicz, Lands of Promise and Despair, 448.

67. Da Silva, Mission Music of California, 111, 120.

68. Yorba manuscript, Ms. C-C-73/108c, song 16, with the title "lla biene 1alba [= Ya viene el alba]. The text proceeds: "[1] lla biene 1alba, rallando el dia, daremos grasias, abe maria [Ave María] / [2] bendita sella [= bendita es ella], la lus del dia, i el angel bello, que vos 1Enbia / [3] Cantemos todos, Con eficasia, nasio maria, llena de grasia / [4] digamos todos, en alta bos, nasio maria, madre de dios / [5] nasio maria, nasieron flores, nase el refujio, de pecadores / [6] nasio maria, para consuelo, de pecadores, i lus del sielo / [7] bella grandesa, no quiso ber, la sierpe cruel, de lusifer / [8] la sierpe fea, llora sus penas, maria le pone, fuertes cadenas / [9] biba Jesus, biba maria, lla quin selebran, en este dia / [10] biba Jesus, biba maria, biba tanbien, la lus del dia / [11] Cantemos todos, Con alegria, digamos todos, Ave Maria / [12] lla bien 1alba, rallando el dia, daremos gracias, abe maria / Amen."

69. "This custom is still in full effect among the paisanos of San Juan Capistrano, especially at the velorios or wakes which begin at $8 \mathrm{PM}$ and do not end until the singing of the alba $(l$ alba $)$ the following dawn." Yorba manuscript, Ms. C-C-73/108c, 1.

70. Saunders and O'Sullivan, Capistrano Nights, 157; Yorba manuscript, Ms. C-C-73/ $108 \mathrm{c}$, song 16.

71. Saunders and O'Sullivan, Capistrano Nights, 153-54.

72. Helen Hunt Jackson, "Echoes in the City of the Angels," Century Illustrated Monthly Magazine (1883), 196, repr. in Howard Swan, Music in the Southwest 18251950 (San Marino, CA: Huntington Library, 1952), 92. 